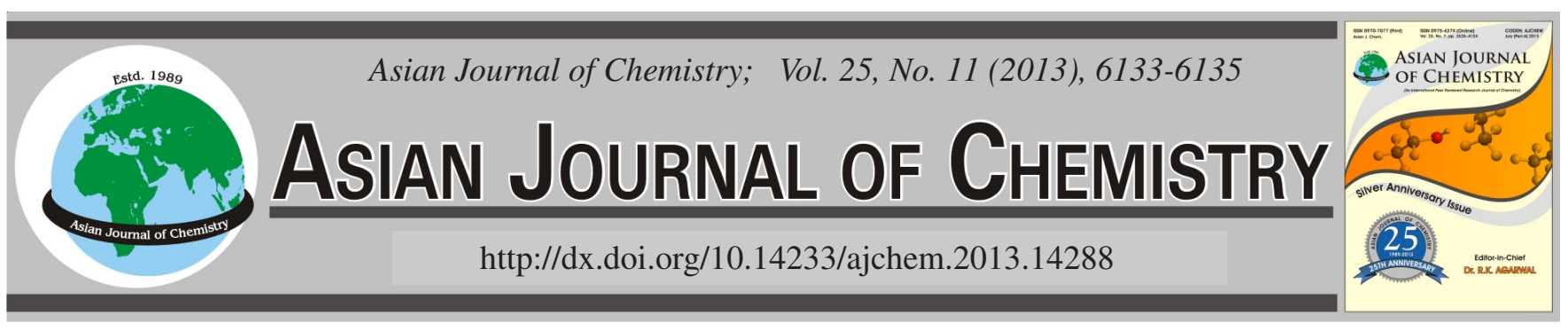

\title{
A New 4-Hydroxyisoflavanone from the Root of Oriental Tobacco and Their Antivirus Activities
}

\author{
Xianxue Wu ${ }^{1,2}$, Yong Xu ${ }^{1}$, Hongeiong Leng ${ }^{1}$, Guangyu Yang ${ }^{1},{\text { Yong-Kuan } \mathrm{Chen}^{1} \text {, Qiufen } \mathrm{Hu}^{3, *} \text { and Miao Mingming }}^{1, *}$
}

${ }^{1}$ Key Laboratory of Tobacco Chemistry of Yunnan Province, Yunnan Academy of Tobacco Science, Kunming 650106, P.R. China ${ }^{2}$ Collge of Resource and Environment, Yuxi Normal University, Yuxi 653100, P.R. China

${ }^{3}$ Key Laboratory of Ethnic Medicine Resource Chemistry (Yunnan University of Nationalities), State Ethnic Affairs Commission \& Ministry of Education, Kunming 650031, P.R. China

*Corresponding author: E-mail: mmmiao@cyats.com; huqiufena@yahoo.com.cn

(Received: 11 July 2012;

Accepted: 30 April 2013)

AJC-13419

A new 4-hydroxyisoflavanone i.e., tobflavanone D (1), was isolated from the roots of oriental tobacco. Its structure was elucidated by
spectroscopic methods, including extensive $1 \mathrm{D}$ and $2 \mathrm{D}$ NMR techniques. Tobflavanone D (1) was tested for their anti HIV-1 activities and
anti-tobacco mosaic virus activities. The results showed that tobflavanone D (1) modest anti HIV-1 activities and antitobacco mosaic virus
activities, respectively.
Key Words: 4-Hydroxyisoflavanone, Oriental tobacco, Anti HIV-1 activities, Antitobacco mosaic virus.

\section{INTRODUCTION}

Nicotiana tabacum $\mathrm{L}$ is a perennial herbaceous plant originating from South America, and it is one of the most commercially valued agricultural crops in the world ${ }^{1,2}$. In addition to cigarette industry use, $N$. tabacum also contains many useful chemical compounds, such as sesquiterpenes ${ }^{3,4}$, diterpenoids $s^{5-7}$, alkaloids ${ }^{8,9}$, phenols ${ }^{10}$, etc. The stems and roots of $N$. tabacum are big amount of by-product in tobacco planting and are normally used as organic fertilizer. The multipurpose utilization of the stems and roots of $N$. tabacum is an interesting topical and receives more and more attentions ${ }^{11-13}$. Motivated by search for bioactive metabolites from this plant, an investigation on the chemical constituents of the roots of oriental tobacco (a variant of $N$. tabacum) was carried out. As a result, a new 4-hydroxyisoflavanone was isolated from this plant. In addition, the anti-tobacco mosaic virus (anti TMV) activity of the new 4-hydroxyisoflavanone was evaluated. This article deals with the isolation, structural elucidation and biological activities of the new compound.

\section{EXPERIMENTAL}

Optical rotation was measured in Horiba SEPA-300 high sensitive polarimeter. IR spectra were obtained in $\mathrm{KBr}$ disc on a Bio-Rad Wininfmred spectrophotometer. ESI-MS were measured on a VG Auto Spec-3000 MS spectrometer. ${ }^{1} \mathrm{H},{ }^{13} \mathrm{C}$ and 2D NMR spectra were recorded on Bruker DRX-500 instrument with TMS as internal standard. Column chroma- tography was performed on silica gel (200-300 mesh), or on silica gel H (10-40 mm, Qingdao Marine Chemical Inc., China). Preparative HPLC was used an Agilent 1100 HPLC equipped with ZORBAX- $\mathrm{C}_{18}(21.2 \mathrm{~mm} \times 250 \mathrm{~mm}, 7.0 \mu \mathrm{m})$ column and DAD detector.

The roots of oriental tobacco were collected in Baoshan Prefecture, Yunnan Province, People's Republic of China, in September 2009. The identification of the plant material was verified by Prof. Chen Y.J. (Yunnan University of Nationalities). A voucher specimen (YNNI 10-9-22) has been deposited in our laboratory.

Extraction and isolation: The air-dried and powdered roots of oriental tobacco $(1.5 \mathrm{~kg})$ were extracted four times with $70 \%$ methanol $(4 \mathrm{~L} \times 2.0 \mathrm{~L})$ at room temperature and filtered. The crude extract (68 g) was applied to silica gel (200300 mesh) column chromatography, eluting with a chloroformacetone gradient system $(20: 1,9: 1,8: 2,7: 3,6: 4,5: 5)$, to give six fractions A-F. The further separation of fraction C $(8: 2$, $13.2 \mathrm{~g}$ ) by silica gel column chromatography, eluted with chloroform-methanol $(9: 1,8: 2,7: 3,6: 4,1: 1)$, yielded mixtures C1-C5. Fraction C2 (9:1, $0.85 \mathrm{~g})$ was subjected to preparative HPLC (42\% methanol, flow rate $12 \mathrm{~mL} / \mathrm{min}$ ) to give 1 (11.6 $\mathrm{mg})$.

Tobflavanone D: Obtained as pale yellow gum; $[\alpha]_{22.5}^{\mathrm{D}}$ 89.2 (c 0.20, MeOH); UV (MeOH), $\lambda_{\max }(\log \varepsilon) 348$ (2.18), 298 (4.05), 210 (4.74) nm; IR (KBr, $v_{\max }, \mathrm{cm}^{-1}$ ): 3398, 2965, 2874, 1738, 1628, 1542, 1475, 1420, 1378, 1228, 1168, 1046, $879 ;{ }^{1} \mathrm{H}$ and ${ }^{13} \mathrm{C}$ NMR data $\left(\mathrm{C}_{5} \mathrm{D}_{5} \mathrm{~N}, 500\right.$ and $\left.125 \mathrm{MHz}\right)$, Table-1; 
ESI-MS (positive ion mode) m/z 383; HR-ESI-MS (positive ion mode) $\mathrm{m} / \mathrm{z} 383.1100[\mathrm{M}+\mathrm{Na}]^{+}$(calcd. (\%) 383.1107 for $\mathrm{C}_{19} \mathrm{H}_{20} \mathrm{NaO}_{7}$ ).

TABLE-1 ${ }^{1} \mathrm{H}$ AND ${ }^{13} \mathrm{C}$ NMR DATA OF TOBFLAVANONE D (1) IN $\mathrm{C}_{5} \mathrm{D}_{5} \mathrm{~N}$

\begin{tabular}{|c|c|c|}
\hline \multirow{2}{*}{ No. } & \multicolumn{2}{|c|}{ Compound $\mathbf{1}$} \\
\hline & $\delta_{\mathrm{C}}$ (mult.) & $\delta_{\mathrm{H}}(\mathrm{mult}, J, \mathrm{~Hz})$ \\
\hline $2 \alpha$ & $66.8(\mathrm{t})$ & $3.61(\mathrm{dd}, J=10.2,11.2)$ \\
\hline $2 \beta$ & - & $4.33(\mathrm{dd}, J=5.2,10.8)$ \\
\hline 3 & $38.8(d)$ & $3.53(\mathrm{~m})$ \\
\hline 4 & $79.0(\mathrm{~d})$ & $5.31(\mathrm{~d}, J=6.9)$ \\
\hline 5 & $115.0(\mathrm{~d})$ & $7.72(\mathrm{~s})$ \\
\hline 6 & $138.8(\mathrm{~s})$ & - \\
\hline 7 & $149.3(\mathrm{~s})$ & - \\
\hline 8 & $104.0(d)$ & $7.27(\mathrm{~s})$ \\
\hline 9 & $148.9(\mathrm{~s})$ & - \\
\hline 10 & $134.1(\mathrm{~s})$ & - \\
\hline $1^{\prime}$ & $120.3(\mathrm{~s})$ & - \\
\hline $2^{\prime}$ & $160.1(\mathrm{~s})$ & - \\
\hline $3^{\prime}$ & $103.3(d)$ & $6.72(\mathrm{~d}, J=2.2)$ \\
\hline $4^{\prime}$ & $155.2(\mathrm{~s})$ & \\
\hline $5^{\prime}$ & $109.1(d)$ & $6.61(\mathrm{dd}, J=2.2,8.6)$ \\
\hline $6^{\prime}$ & $125.0(\mathrm{~d})$ & $7.03(\mathrm{~d}, J=8.6)$ \\
\hline 7-OMe & $55.8(q)$ & $3.81(\mathrm{~s})$ \\
\hline $2^{\prime}-\mathrm{OMe}$ & $55.9(\mathrm{q})$ & $3.78(\mathrm{~s})$ \\
\hline $4^{\prime}-\mathrm{OAc}$ & $21.2 \mathrm{q}, 170.0 \mathrm{~s}$ & $1.91(\mathrm{~s})$ \\
\hline $6-\mathrm{OH}$ & - & 11.21 (brs) \\
\hline
\end{tabular}

\section{RESULTS AND DISCUSSION}

A $70 \%$ aq. methanol extract prepared from the roots of oriental tobacco was subjected repeatedly to column chromatography and preparative HPLC to afford compound 1. Its structure was shown in Fig. 1 and its ${ }^{1} \mathrm{H}$ and ${ }^{13} \mathrm{C}$ NMR spectroscopic data were listed in Table-1.

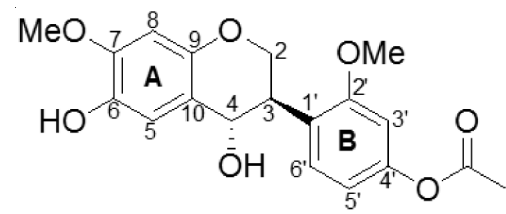

Fig. 1. Structure of tobflavanone D (1)

Tobflavanone D (1) was obtained as pale yellow gum. Its molecular formula was determined as $\mathrm{C}_{19} \mathrm{H}_{20} \mathrm{O}_{7}$ by HR-ESI$\mathrm{MS} \mathrm{m} / \mathrm{z} 383.1100[\mathrm{M}+\mathrm{Na}]^{+}$(calcd. (\%) 383.1107). Its ${ }^{1} \mathrm{H}$ and ${ }^{13} \mathrm{C}$ NMR spectra data (Table-1) showed signals to 20 hydrogens and 19 carbons, respectively, corresponding to two aromatic rings with five aromatic protons, one oxidated methine group $\left(\delta_{\mathrm{C}} 79.0\right)$, one methine groups $\left(\delta_{\mathrm{C}} 38.8\right)$ one oxidated methylene group $\left(\delta_{\mathrm{C}} 66.8\right)$, two methoxy group $\left(\delta_{\mathrm{C}}\right.$ $55.8,55.9)$, an acetoxy group $\left(\delta_{\mathrm{C}} 21.2,170.0\right)$ and a phenolic hydroxyl group $\left(\delta_{\mathrm{H}} 11.21\right)$. Strong absorption bands accounting for hydroxyl $\left(3398 \mathrm{~cm}^{-1}\right)$, acetoxy $\left(1738 \mathrm{~cm}^{-1}\right)$ and aromatic groups $\left(1628,1542,1475,1420 \mathrm{~cm}^{-1}\right)$ could also be observed in its IR spectrum. The UV spectrum of tobflavanone D (1) showed absorption maxima at 298, $210 \mathrm{~nm}$ confirmed the existence of the aromatic functions. The ${ }^{1} \mathrm{H}$ NMR spectrum showed a pair of doublets at $\delta_{\mathrm{H}} 3.61(J=10.2,11.2 \mathrm{~Hz}), \delta_{\mathrm{H}}$ $4.33(J=5.2,10.8 \mathrm{~Hz})$, a multiplet at $\delta_{\mathrm{H}} 3.54(\mathrm{~m})$ and a doublet at $\delta_{\mathrm{H}} 5.31(\mathrm{~J}=6.9 \mathrm{~Hz})$. These signals were assignable to $\mathrm{H}-2$, H-3 and H-4 protons of a 4-hydroxyisoflavanone skeleton ${ }^{14}$, respectively. The typical proton signals at $\left(\delta_{\mathrm{H}} 7.72 \mathrm{~s} 1 \mathrm{H}\right)$ and $(7.27 \mathrm{~s} 1 \mathrm{H})$ revealed that the ring A should be a 6,7-substituted moiety ${ }^{15}$. Proton signals at $\delta_{\mathrm{H}} 6.72(J=2.2 \mathrm{~Hz}), \delta_{\mathrm{H}} 6.61(\mathrm{~J}=$ $2.2,8.6 \mathrm{~Hz})$ and $\delta_{\mathrm{H}} 7.03(J=8.6 \mathrm{~Hz})$ also revealed that the ring B should be $2^{\prime}, 4^{\prime}$-disubstituted ${ }^{16}$. The HMBC correlations (Fig. 2) of phenolic hydroxy proton signal $\left(\delta_{\mathrm{H}} 11.21\right)$ with $\mathrm{C}-5$ $\left(\delta_{\mathrm{C}} 115.0\right), \mathrm{C}-6\left(\delta_{\mathrm{C}} 138.8\right)$ and $\mathrm{C}-7\left(\delta_{\mathrm{C}} 149.3\right)$ indicated that the phenolic hydroxy group should be located at C-6. Two methoxy groups located at C-7 and C-2' was supported by the HMBC correlations of the methoxy proton signals $\left(\delta_{\mathrm{H}} 3.81\right.$, $3.77)$ with $\mathrm{C}-7\left(\delta_{\mathrm{C}} 149.3\right)$ and $\mathrm{C}-2^{\prime}\left(\delta_{\mathrm{C}} 160.1\right)$, respectively. This was further confirmed through the NOESY correlations (Fig. 3) between OMe-7 $\left(\delta_{\mathrm{H}} 3.81\right)$ with $\mathrm{H}-8\left(\delta_{\mathrm{H}} 7.27\right)$ and OMe$2^{\prime}\left(\delta_{\mathrm{H}} 3.78\right)$ with H-3' $\left(\delta_{\mathrm{H}} 6.72 \mathrm{~J}=2.2 \mathrm{~Hz}\right)$, respectively. The position of methoxy and hydroxy groups was be determined, the acetoxy group should be located at C-4' accordingly.

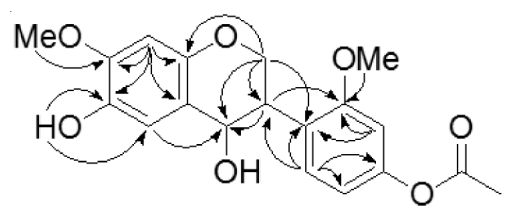

Fig. 2. Selected HMBC ( $\neg$ ) correlations of $\mathbf{1}$

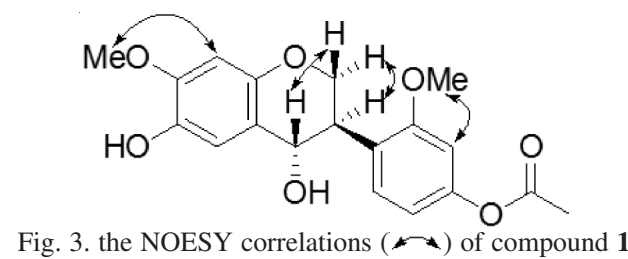

The larger magnitude of coupling constants between $\mathrm{H}-2 \beta$ and $\mathrm{H}-3$ inferred $\alpha$ and pseudoaxial orientation of $\mathrm{H}-3$. Moreover, the larger coupling constant between $\mathrm{H}-3$ and $\mathrm{H}-4$ revealed their trans relationship and indicating $\beta$ orientation of $\mathrm{H}-4$. The relative stereochemistry at C-3 and C-4 were established as shown, which was confirmed by strong NOESY correlations between $\mathrm{H}-4$ and $\mathrm{H}-2 \beta$ and between $\mathrm{H}-3$ and $\mathrm{H}-2 \alpha$ and also by ${ }^{1} \mathrm{H}$ and ${ }^{13} \mathrm{C}$ NMR chemical shifts of $\mathrm{C}-2$, $\mathrm{C}-3$ and $\mathrm{C}-4$, which showed complete agreement with those of conferol $\mathrm{A}^{14}$ and bolusanthol $\mathrm{A}^{17}$. Thus, structure of tobflavanone D (1) was determined as 4,6-dihydroxy-7,2'-trimethoxy-4'acetoxyl-isoflavanone and named as cordifoliflavanone A.

Since some of the flavonoids exhibited anti virus activities $^{18-20}$, compounds $\mathbf{1}$ was tested for their anti HIV-1 activities and anti tobaco mosaic virus activities.

The anti HIV-1 activities were tested for their potencies in preventing the cytopathic effects of HIV-1 in C8166 and cytotoxicity measured in parallel with the determination of antiviral activity, using AZT as a positive control $\left(\mathrm{EC}_{50}=0.045\right.$ $\mu \mathrm{g} / \mathrm{mL}$ and $\left.\mathrm{CC}_{50}>200 \mu \mathrm{g} / \mathrm{mL}\right)^{21}$. Compound 1 showed modest anti HIV-1 activities with $\mathrm{EC}_{50}$ value of $2.68 \mu \mathrm{g} / \mathrm{mL}$ and minimal cytotoxicity against $\mathrm{C} 8166$ cells $\left(\mathrm{CC}_{50}>200 \mu \mathrm{g} / \mathrm{mL}\right)$. The therapeutic index (TI) values $\left(\mathrm{CC}_{50} / \mathrm{EC}_{50}\right)$ of $\mathbf{1}$ were more than 69.9 .

The anti tobacco mosaic virus activities were tested using the half-leaf method ${ }^{22}$. The inhibitory activities of the new 
compounds (at the concentration of $20 \mu \mathrm{M}$ ) against tobaco mosaic virus replication were tested using two approaches. First, the half-leaf method was used to test the antiviral activity in the local lesion host $N$. glutinosa in vivo. Then, the leafdisk method was used to evaluate the antiviral activity of the compound in the systemic infection host $N$. tabacum cv. K326. Ningnanmycin (2\% water solution), a commercial product for plant disease in China, was used as a positive control. The results showed that the compound $\mathbf{1}$ exhibited inhibition rates of $8.26 \%$.

\section{ACKNOWLEDGEMENTS}

This project was supported financially by the Basic Research Foundation of Yunnan Tobacco Industry Co. Ltd. (2012JC01), the Excellent Scientific and Technological Team of Yunnan High School (2010CI08), and Open Research Fund Program of Key Laboratory of Ethnic Medicine Resource Chemistry (Yunnan University Nationalities) (2010XY08.

\section{REFERENCES}

1. The Editorial Committee of the Administration Bureau of Flora of China, Flora of China, Beijing Science and Technology Press, Beijing, Vol. 67 (2005).

2. T.W. Hu and Z. Mao, Tob. Control, 15, i37 (2006).

3. X. Feng, Xin, J.S. Wang, J. Luo and L.Y. Kong, J. Asian Nat. Prod. Res., 12, 252 (2010).

4. X. Feng, Xin, J.S. Wang, J. Luo and L.Y. Kong, J. Asian Nat. Prod. Res., 11, 675 (2009).

5. W. Inger, W. Ingrid, N. Kerstin, N. Toshiaki, R.E. Curt, W.R. William, Y. Noboru and Y. Chizuko, Acta Chem. Scand., 33b, 541 (1979).
6. Y. Shinozaki, T. Tobita, M. Mizutani and T. Matsuzaki, Biosci. Biotechnol. Biochem., 60, 903 (1996).

7. T. Petterson, A.M. Eklund and I. Wahlberg, J. Agric. Food. Chem., 41, 2097 (1993)

8. X.C. Wei, S.C. Sumithran, A.G. Deaciuc, H.R. Burton, L.P. Bush, L.P. Dwoskin and P.A. Crooks, Life. Sci., 78, 495 (2005).

9. T. Braumann, G. Nicolaus, W. Hahn and H. Elmenhorst, Phytochemistry, 29, 3693 (1990).

10. D. Vereecke, E. Messens, K. Klarskov, A. Bruyn, M. Montagu and K. Goethals, Planta, 201, 342 (1997).

11. W. Li, L.B. Zhang, J.H. Peng, N. Li and X.Y. Zhu, Ind. Crop. Prod., 27, 341 (2008).

12. B.B. Zhang, C.J. Xie and X.Y. Yang, Peptides, 29, 350 (2008).

13. W.H. Zhong, C.J. Zhu, M. Shu, K.D. Sun, L. Zhao, C. Wang, Z.J. Ye and J.M. Chen, Bioresour. Technol., 101, 6935 (2010).

14. R. Khan, A. Malik, A. Adhikari, M.I. Qadir and M.I. Choudhary, Chem. Pharm. Bull., 57, 415 (2009).

15. R.Q. Mei, Q. Lu, Y.F. Hu and Y.X. Cheng, Chin. J. Nat. Prod. Res. Develop., 22, 238 (2010)

16. D.Q. Yu and J.S. Yang, Handbook of Analytical Chemistry, Nuclear Magnetic Resonance Spectroscopy, Chemical Industry Press, Beijing, edn. 2, Vol. 7, p. 323 (1999).

17. G. Bojase, C.C.W. Wanjala and R.R.T. Majinda, Phytochemistry, 56, 837 (2001)

18. E. Tripoli, M. Guardia, S. Giammanco, D. Majo and M. Giammanco, Food. Chem., 104, 466 (2007).

19. M.T.K. Hassan and A. Ather, Biotechnol. Ann. Rev., 13, 223 (2007).

20. B. Malhotra, J.C. Onyilagha, B.A. Bohm, G.H.N. Towers, D. James, J.B. Harborne and C.J. French, Phytochemistry, 43, 1271 (1996).

21. H. Wang, S.C. Tam, H. Huang, D.Y. Ouyang, Y.Y. Wang and Y.T. Zheng, Biochem. Biophys. Res. Commun., 317, 965 (2004).

22. X.H. Yan, J. Chen, Y.T. Di, X. Fang, J.H. Dong, P. Sang, Y.H. Wang, H.P. He, Z.K. Zhang and X.J. Hao, J. Agric. Food. Chem., 58, 1572 (2010). 